\title{
Fatherhood dan Indeks Prestasi (IP) Akademik pada Mahasiswa Fakultas Pendidikan Psikologi, Universitas Negeri Jakarta
}

\author{
Bijak Aditia Hutomo1, Fathimah Miftahul Jannah', Tahlia Latifah ${ }^{3}$ \\ 1,2,3Fakultas Pendidikan Psikologi, Universitas Negeri Jakarta \\ bijak.aditia@gmail.com
}

\begin{abstract}
Education is one of the fundamental things that are needed by humans, as well as the assistance received. As part of education, students are people who are in the development of adolescents into early adulthood. In some theories, adolescents are more involved with peers than their parents. Associated with peers does not mean that teens are not fully involved with their parents. This research is a quantitative descriptive study that aims to find a picture of Fatherhood and Academic Achievement Index in the Students of the Faculty of Psychology Education, Jakarta State University. The literature has proven the results of the contribution of fathers have a very large contribution to the academic achievement of children aged 13-15 years. The measuring instrument used in this study is The Fatherhood Scale developed by Gary L. Dick in 2016. The population and sample of this study were students of the Faculty of Psychology Education in 2016 and 2017. The results of this study were supported by published research and the Achievement Index (IP) Academic that exists in students.
\end{abstract}

\begin{abstract}
Abstrak: Pendidikan merupakan salah satu hal mendasar yang sangat dibutuhkan oleh manusia, sama halnya dengan pengasuhan orangtua. Sebagai bagian dari pendidikan, mahasiswa merupakan seseorang yang berada dalam tahapan perkembangan remaja menuju dewasa awal. Dalam beberapa teori, remaja lebih cenderung terlibat dengan teman sebaya daripada orangtuanya. Keterlibatan yang lebih pada teman sebaya tidak berarti remaja tidak terlibat secara seutuhnya dengan orang tuanya. Penelitian ini merupakan penelitian deskriptif kuantitatif yang bertujuan mencari gambaran Fatherhood dan Indeks Prestasi Akademik pada Mahasiswa Fakultas Pendidikan Psikologi, Universitas Negeri Jakarta. Literatur lain menunjukkan bahwa keterlibatan ayah memiliki kontribusi yang sangat besar pada prestasi akademik anak usia 13-15 tahun. Alat ukur yang digunakan dalam penelitian ini adalah The Fatherhood Scale yang dikembangkan oleh Gary L. Dick pada tahun 2016. Populasi dan Sampel dari penelitian ini adalah mahasiswa Fakultas Pendidikan Psikologi angkatan 2016 dan 2017. Hasil dari penelitian ini diharapkan mampu menjadi gambaran sederhana mengenai bagaimana Fatherhood dan Indeks Prestasi (IP) Akademik yang ada pada mahasiswa.
\end{abstract}

Keyword: Fatherhood, Mahasiswa, Indeks Prestasi Akademik

\section{Pendahuluan}

Menurut Kamus Besar Bahasa Indonesia ayah diartikan sebagai kata sapaan kepada orang tua kandung laki-laki. Ayah dalam peranannya memiliki tanggiung jawab yang cukup besar. Verkuyl dalam Harmaini, Shofiah, Yulianti (2014) menyebutkan bahwa peran seorang ayah pada tahun-tahun pertama dalam kehidupan anak adalah membantu ibu 


\section{WACANA}

memberikan perawatan. Setelah itu ayah menjadi kepala keluarga yang berwibawa dan mempertahankan serta melindungi kehidupan keluarga.

Fungsi seorang ayah adalah hidup dan bekerja pada perbatasan antara keluarga dan masyarakat, antara "dalam" dan "luar." Ayah memperkenalkan dan membimbing anakanaknya untuk mengarungi dunia luar atau kehidupan bermasyarakat. Sedangkan Halverson (2002) berpendapat bahwa ayah bertanggung jawab atas tiga tugas utama. Pertama, ayah haruslah mengajar anaknya tentang Tuhan dan mendidik anaknya dalam ajaran agama. Kedua, seorang ayah haruslah mengambil peran sebagai pimpinan dalam keluarganya. Ketiga, ayah haruslah bertanggung jawab atas disiplin.

Pengasuhan anak biasanya identik dilakukan oleh seorang ibu. Peran ayah dalam pengasuhan sering kali diabaikan. Terlebih mitos yang berkembang di kalangan masyarakat menjadikan pengasuhan ayah sebagai hal yang dianggap tidak biasa. Barthes (2010) dalam Elly Manika Maya Mahadi (2016) mengatakan bahwa mitos adalah sesuatu yang dideterminasi oleh wacana sosial, ia merupakan "refleksi". Ayah diidentikkan sebagai seseorang yang hanya memiliki peranan sebagai pemenuh kebutuhan keluarga untuk mencari nafkah. Banyak ayah yang menganggap hanya dengan memberikan materi berupa barang, makanan, dan uang sudah cukup dan selesai tugasnya. Bahkan Indonesia sendiri dapat dijuluki fatherless country karena peran ayah yang sangat minim dalam kehidupan sang anak (Bendri, 2015).

Kebanyakan orang sudah merasa cukup dengan pola asuh dari ibu saja. Ibu diberi kepercayaan penuh dalam mendidik dan membesarkan seorang anak. Padahal, lebih dari itu peran ayah begitu besar dalam tumbuh kembang anak. Di dalam Al-Qur'an ayat yang membahas tentang dialog pengasuhan berjumlah 17 ayat dimana 14 ayat bercerita tentang dialog ayah dan anak, 2 ayat dialog ibu dan anak serta 1 ayat dialog guru dan murid. Dari jumlah ayat dalam Al-Qur'an ini saja sudah menunjukkan bahwa proporsi pola asuh ayah atau peran ayah dalam mendidik anak begitu besar. Karena figur kepemimpinan seorang ayah mampu mengajarkan anak banyak hal.

Begitupun peran ayah untuk mendampingi buah hatinya dalam menjalani proses akademik. Mahadi (2016) mengatakan bahwa fatherhood terdiri dari beberapa elemen, yakni : "intimacy" (kedekatan emosional dengan anak), "provision” (memungkinkan seorang 


\section{WACANA}

pasangan mengasuh anak; menentukan standar materi bagi kehidupan keluarga), "protection" (dari bahaya fisik maupun pengaruh negatif), dan "endowment" (memberikan waktu, uang, dan tenaga untuk anak atau keluarga; membuat kesempatan positif untuk berolahraga, pembelajaran, dan sekolah; menganugerahkan anak dengan karakter (Townsend dalam Jensen, 2015:615).

Menurut Harmani, Shofiah, dan Yulianti (2014) terdapat beberapa kewajiban orang tua, yang paling utama dan pokok, yaitu 1) Hak anak atas orang tuanya, hendaklah orang tuanya memberi nama yang baik kepadanya, dan mendidiknya dengan baik, dan menempatkannya (tempat tinggal) di tempat yang baik/shaleh. 2) Kewajiban orang tua terhadap anak adalah : membaguskan namanya dan akhlak/sopan santun, mengajarkan tulis menulis, berenang, dan memanah, memberi makan dengan makanan yang baik, menikahkannya bila telah cukup umur."

Dari 2 riwayat tersebut, setidaknya ada 5 kewajiban orang tua terhadap anak. 1) Memberi nama yang baik, 2) Mendidiknya dengan pendidikan yang terbaik, 3) Mengajarkan keahlian dan ketangkasan kepada anak. Seperti keahlian membaca dan menulis, dalam konteks sekarang mungkin anak diajarkan agar menguasai komputer, bahasa asing dll. Ketangkasan dan keberanian, dapat diajarkan melalui latihan berenang dan memanah, maupun olah raga lainnya. 4) Menempatkan di tempat tinggal yang baik dan memberi rezki dari yang baik. 5) Menikahkan anak bila sudah cukup umur. Ini merupakan kewajiban utama orang tua yang terakhir, yang mesti dilakukan terhadap anak-anaknya. Karena ketika anak-anaknya sudah berumah tangga, biasanya anak akan memisahkan diri dari rumah orang tuanya dan membina rumah tangga dengan pasangannya.

Peran ayah yang tidak optimal jelas memiliki pengaruh yang cukup besar terhadap tumbuh kembang anak. Menurut Salsabila (2017) apabila seorang anak sama sekali tidak merasakan peran dari seorang ayah maka dia akan merasa kesulitan untuk melakukan adaptasi baik di sekolah, lingkungan sosial atau pun dalam perubahan yang lain. Hasil dari riset juga menunjukan bahwa seorang anak yang tanpa peran ayah: Sebanyak 63\% anak akan mengalami masalah psikologis seperti: merasa gelisah, suasana hati yang mudah sekali berubah, fobia, dan juga depresi. Sebanyak 56\% lebih memiliki daya tangkap di bawah rata-rata. Sebanyak $43 \%$ anak sangat agresif terhadap orang tua." 


\section{WACANA}

Dari pernyataan di atas jelas menggambarkan betapa pentingnya pengasuhan yang dilakukan oleh ayah. Peran ayah memiliki andil dalam perkembangan psikis, kemampuan daya tangkap anak dan juga sikap agresif anak terhadap orang tuanya.

Dampak besar akibat tidak hadirnya ayah di tengah keluarga terutama kehadiran ayah dalam tahap tumbuh kembang anak, seperti yang disampaikan oleh seorang motivator dan terapis, Shanti (2017) adanya rasa kekecewaan pada keluarga, bahwa di dalam keluarga, peran ayah sangat lemah. Di sini menjadi sumbangsih dan cikal bakal seseorang menjadi LGBT.

Peran ayah tidak dijalanakan dengan baik maka akan berdampak terhadap perkembangan diri anak. Masa-masa kuliah merupakan masa transisi seseorang dari remaja menuju dewasa awal di mana pada tahap ini peranan ayah memiliki andil yang cukup penting dalam kontrol anak. Secara umum, mereka yang tergolong dewasa awal adalah mereka yang berusia 20-40 tahun (Hurlock, 1986). Pada usia ini peran ayah adalah peran yang sangat dibutuhkan oleh seorang anak, hal ini sesuai dengan pernyataan Santrock (2005) yang mengatakan bahwa ayah yang memiliki interaksi yang sangat perhatian, akrab, dan dapat diandalkan oleh anak dapat memberi pengaruh yang baik terhadap pertumbuhan sosial remaja.

Oleh karena itu, melihat pentingnya peran ayah dalam perkembangan anak, motivasi belajar anak, dan kecerdasan anak peneliti mencob untuk mencari tahu jawaban yang berkaitan dengan kedua hal tersebut, khususnya pada mereka yang berstatus sebagai mahasiswa dengan judul Fatherhood dan Indeks Prestasi (IP) Akademik pada Mahasiswa Fakultas Pendidikan Psikologi, Universitas Negeri Jakarta.

\section{Metode}

Penelitian ini adalah sebuah penelitian deskriptif yang dilakukan pada bulan November tahun 2018. Sangadji \& Sopiah (2010:29) mengatakan bahwa penelitian deskriptif adalah penelitian yang dilakukan untuk mengetahui nilai variabel mandiri tanpa membuat perbandingan atau menghubungkan dengan variabel lain. Populasi dari penelitian ini adalah Mahasiswa Fakultas Pendidikan Psikologi. Sampel pada penelitian ini diambil dengan menggunakan aksidental sampling. Sampel berjumlah 50 mahasiswa yang berasal dari angkatan 2016-2017. Pengambilan data dilakukan dengan menggunakan 


\section{WACANA}

kuesioner online yang berisikan 64 pernyataan yang dijawab dengan menentukan rating scale yang berisikan soal dari Fatherhood Scale yang dikembangkan oleh Gary L. Dick. Analisis data dilakukan dengan cara menarik kesimpulan inti dari setiap jawaban yang bersifat deskriptif. Inti dari jawaban yang diberikan responden kemudian dimasukan ke dalam beberapa kategori yang mewakilkan jawabannya.

\section{Hasil Penelitian}

Dalam penelitian ini, kami menggunakan fatherhood scale yang dikembangkan oleh Gary L. Dick dengan reliabilitas keseluruhan 0,98. Skala ini memiliki sembilan kategori subtes yang dijawab oleh responden dengan memilih skala tidak pernah, jarang, sesekali, sering, dan selalu. Responden yang terlibat dalam penelitian ini adalah : 1) Mahasiswa Fakultas Pendidikan Psikologi. 2) Merupakan angkatan 2016-2017 3). Berjenis kelamin laki-laki

Data demografi dari total 50 sampel yang kami dapatkan adalah 6\% berusia 18 tahun, 43\% berusia 19 tahun, 31\% berusia 20 tahun, 18\% berusia 21 tahun, dan $2 \%$ berusia 22 tahun. Pada saat data diambil responden yang tinggal bersama orang tua sebanyak 83\%, 13\% lainnya tinggal bersama saudara seperti paman, atau kakeknya. Sementara 4\% lainnya tinggal bersama orang tua. Responden terdiri dari 42\% angkatan 2016 dan 58\% angkatan 2017

\begin{tabular}{|l|c|c|}
\hline Usia & $\mathbf{N}$ & $\mathbf{\%}$ \\
\hline 18 tahun & 3 & $6 \%$ \\
\hline 19 tahun & 21 & $43 \%$ \\
\hline 20 tahun & 15 & $31 \%$ \\
\hline 21 tahun & 9 & $18 \%$ \\
\hline 22 tahun & 1 & $2 \%$ \\
\hline Status Tinggal & & \\
\hline Tinggal bersama orang tua & 43 & $83 \%$ \\
\hline Tinggal bersama saudara & 2 & $13 \%$ \\
\hline Tinggal di kost/sendiri & 7 & $4 \%$ \\
\hline Angkatan & & \\
\hline 2016 & 21 & $42 \%$ \\
\hline 2017 & 29 & $58 \%$ \\
\hline
\end{tabular}

Tabel 1 


\section{WACANA}

The Fatherhood Scale merupakan sebuah instrumen yang digunakan untuk mengukur bagaimana hubungan individual seorang laki-laki dengan ayahnya (Dick, 2004). Instrumen ini disajikan dalam bentuk skala likert dengan lima pilihan jawaban dimana untuk membuat kesimpulan semua respon jawaban dijumlahkan. Instrumen ini memiliki 64 item dengan 53 favorable item dan 11 unfavorable item (Dick, 2004). Skor yang berada dibawah 128 akan berada pada kategori rendah, dimana ayah jarang terlibat dalam kegiatan positif dengan anak. Sedangkan 128-256 dikategorikan sedang dimana keterlibatan ayah biasa saja dengan anak. Sedangkan skor diatas 256 dikategorikan tinggi, dimana ayah terlibat secara positif dengan anak (Dick, 2004). Rata-rata skor pada studi ini adalah 209 (SD: 44,28) dengan hasil 14\% memiliki keterlibatan positif dengan ayah, 80\% dikategorikan sedang dalam keterlibatan dengan ayah, dan 6\% dikategorikan rendah dalam keterlibatannya.

Berdasarkan ketiga kategori tersebut ditemukan bahwa mahasiswa dengan keterlibatan yang tinggi dan positif dengan ayahnya memiliki rata-rata Indeks Prestasi Kumulatif (IPK) lebih tinggi dibandingkan dengan yang memiliki keterlibatan ayah sedang dan rendah, yaitu 3,24. Sedangkan bagi mereka yang memiliki keterlibatan ayah yang sedang adalah 3,23 dan yang kurang terlibat secara positif adalah 3.08. Proporsi dari ketiga kategori tersebut adalah 7 orang dengan keterlibatan tinggi dan positif, 40 keterlibatan sedang, dan 3 keterlibatan rendah. Sedangkan untuk proporsi usianya sendiri adalah sebagai berikut.

\begin{tabular}{|c|c|c|c|}
\hline Usia & Terlibat Positif & Terlibat Sedang & Kurang Terlibat \\
\hline 18 & 2 & 1 & - \\
\hline 19 & 1 & 19 & 2 \\
\hline 20 & 2 & 12 & 1 \\
\hline 21 & 2 & 7 & - \\
\hline 22 & - & 1 & - \\
\hline
\end{tabular}

Tabel 2

\section{Diskusi}

William J. Haynes menulis dalam artikel yang berjudul "A Meta -Analysis: The Relationship between Father's Involvement and Student Academic Achievement" meneliti tentang pengaruh antara keterlibatan ayah dengan prestasi akademik anak dan melakukan beberapa studi literasi dengan membandingkan berbagai teori tentang hal tersebut dengan subjek yang memiliki rentang usia beragam. Secara keseluruhan hasil penelitian meta- 


\section{WACANA}

analisis yang ia lakukan mengindikasikan bahwa adanya pengaruh antara keterlibatan ayah dalam pola asuh pada anak dengan akademik, kondisi psikologis dan sebagainya, mulai dari anak usia Taman Kanak-Kanak hingga usia 20 tahun (Haynes, 2015). Pengaruh keterlibatan ayah inilah yang sangat diharapkan dan dibutuhkan oleh remaja akhir atau dewasa awal seperti mahasiswa untuk mengontrol dan mengawasi anak (Hurlock 1986).Ketika anak mendapatkan perhatian, memiliki keakraban dan dekat dengan sang anak hal tersebut tentu memberikan pengaruh yang baik untuk pertumbuhan sosial anak dan mampu meningkatkan motivasi belajar dan perilaku adaptif sang anak di dunia perkuliahan ( Santrock, 2005)

Hal ini ditunjukkan dengan gambaran dari penelitian yang kami lakukan untuk mahasiswa Fakultas Pendidikan Psikologi Universitas Negeri Jakarta dimana rata-rata IPK yang cenderung lebih tinggi di pada mereka yang mendapatkan keterlibatan ayah dalam pola asuh yang tinggi

\section{Simpulan}

Keterlibatan ayah dalam pola asuh keluarga berpengaruh pada prestasi akademik anak. Hal ini dibuktikan dengan data penelitian kami dimana anak dengan keterlibatan pola asuh ayah yang tinggi dan positif memiliki rata-rata Indeks Prestasi Kumulatif (IPK) lebih tinggi dibandingkan dengan yang memiliki keterlibatan ayah sedang dan rendah.

Keterbatasan dari penelitian adalah kurangnya sampel yang terlibat dalam penelitian ini. Keterbatasan kedua adalah minimnya ketersediaan akan literatur mengenai father's involvement dengan student achievement khususnya untuk usia perkembangan dewasa awal. Kebanyakan studi mengenai father involvement terdapat pada subjek remaja dan anak-anak

\section{Daftar Pustaka}

Bila, Salsa. Inilah Pentingnya Peran Seorang Ayah Untuk Kecerdasan Anak. http://sayangianak.com/inilah-pentingnya-peran-seorang-ayah-untuk-kecerdasananak/ (diakses 24 November 2018)

Dick, Gary L. The Fatherhood Scale. Research on Social Work Practice. 2004: 14(2) 80-92. 


\section{WACANA}

Dosenpsikologi.com. 13 Peran Ayah Dalam Perkembangan Remaja. https://dosenpsikologi.com/peran-ayah-dalam-perkembangan-remaja (diakses 24 November 2018)

Harmaini, Shofah V. , Yulianti A. . Peran Ayah Dalam Mendidik Anak. Jurnal Psikologi: 80-82.

Jeynes, W. H. A Meta-Analysis: The Relationship Between Father Involvement and Student Achievement. Urban Education. 2015: 50(4) 414-415

Luwita Assa, Tiara. 2016. Keterlibatan Ayah Dalam Pengasuhan Menurut Remaja Perempuan Perokok. Jurusan Psikologi. Fakultas Psikologi. Universitas Sanata Dharma.

Manika Maya Mahadi, Elly. 2016. Presentasi Fatherhood Dalam Majalah Ayahbunda. Jurusan Ilmu Komunikasi. Fakultas Ilmu Sosial Dan Ilmu Politik. Universitas Diponegoro.

Nina Zulida Situmorang1, Yuliatmi Pratiwi2, Dan Dimas Panji Agung R. Peran Ayah Dan Kontrol Diri Sebagai Preditor Kecenderungan Perilaku Agresif Remaja. Muara Ilmu Islam: Vol 2. 116-118.

Zuhairah, Tatar F. M. Hubungan Antara Keterlibatan Ayah Dalam Pengasuhan Dengan Kenakalan Remaja Di Kota Banda Aceh. 2017. Jurnal Pencerahan: 11. 46-47. 